\title{
Knowing the Heart of the Stranger: Empathy, Remembrance, and Narrative in Jewish Reception of Exodus 22:2 I, Deuteronomy 10:19, and Parallels
}

\author{
Interpretation: A Journal of \\ Bible and Theology \\ 2018, Vol. 72(2) || $|9-13|$ \\ (C) The Author(s) 2018 \\ Reprints and permissions: \\ sagepub.co.uk/journalsPermissions.nav \\ DOI: 10.1 I 177/00209643। 17749540 \\ journals.sagepub.com/home/int \\ @SAGE
}

\section{Shani Tzoref}

University of Potsdam, Potsdam, Germany

\begin{abstract}
With its exhortation "You shall also love the stranger (gēr), for you were strangers (gērîm) in the land of Egypt" (Deut 10:19), the book of Deuteronomy helps cultivate a healthy and appreciative sense of past hardship, current prosperity, progress, and relative privilege. In contemporary culture, where the term "privilege" has become an unfortunate source of contention, Deuteronomy might point a way for recognition of one's relative privilege in regard to an Other as a basis for gratitude and responsibility. This essay argues that we have gained "privilege" after having been immigrants and strangers in a strange land. Privilege could become an empowering and challenging exercise of counting one's blessings and considering how these could be used for the benefit of others, including strangers in our land.
\end{abstract}

\section{Keywords}

Continuity; Empathy; gēr; gērîm; Hospitality; Identity; Imitatio Dei; Immigrants; Memory; Narrative; Other; Privilege, Rabbinic exegesis; Stranger; Trauma

\section{Introduction}

Deuteronomy 10:19 commands, "You shall also love the stranger (Hebrew, gēr), for you were strangers (gērîm) in the land of Egypt." Similarly, Exod 22:21 (Exod 20:20 MT) adjures, "You shall not wrong or oppress a resident alien $(g \bar{e} r)$, for you were aliens ( $g \bar{e} r \hat{\imath} m)$ in the land of Egypt." The connection between the divine command and Israel's national-historical narrative is even more explicit in Exod 23:9, "You shall not oppress a resident alien ( $g \bar{e} r)$; you know the heart of an alien ( $g \bar{e} r)$, for you were aliens (gērîm) in the land of Egypt."

These verses are just three of the numerous references to compassionate treatment of the geer in the Pentateuch. The Talmud (b. Bava Metzia 59b) quotes one sage as stating an early rabbinic

\section{Corresponding author:}

Shani Tzoref, University of Potsdam, Am Neuen Palais 10, House 9, 14469 Potsdam, Germany.

Email: stzoref@uni-potsdam.de 
teaching that "the Torah issues warnings in 36 places - and some say in 46 places - with regard to causing any distress to a ger." " It has become popular in contemporary contexts, to cite this "statistic" homiletically - to stress the importance that Judaism places on loving the stranger. This is a tradition that can naturally be quite appealing to those who seek authoritative textual foundations for our religiously inspired embrace of modern humanist Western-liberal attitudes to the stranger, or in postmodern parlance, the "Other."

The rhetorical usage, however, is not quite as smooth as it appears. In this essay, I will unpack some of the tensions that are contained within this talmudic passage, exploring ancient and contemporary reception history of the Pentateuchal commandments about treatment of the $g \bar{e} r$ in Jewish tradition. I aim to stimulate consideration of interpretations that can be effectively harnessed today, in the context of the many fears and challenges posed by global migration, and particularly attitudes toward asylum-seekers. The champions of respect for the Other who cite the Talmudic statement in b. Bava Metzia 59b tend not to cite the full text, which is as follows:

It is taught in a baraita that Rabbi Eliezer the Great says: For what reason did the Torah issue warnings in thirty-six places, and some say in forty-six places, with regard to causing any distress to a convert (gerr)?

It is due to the fact that a convert's inclination is evil, i.e., he is prone to return to his previous way of living. ${ }^{2}$

In the original passage, the reference to the numerous warnings is not taken as evidence of "concern for social justice," but rather as an expression of suspicion about the $g \bar{e} r$. Moreover, from the context, it is clear that the term geer is not understood as a complete outsider, but rather designates a convert to Judaism. I will therefore explore the questions: who is the ger $r$ in the Hebrew Bible and in later Jewish reception? And, to what extent do the various texts reflect and advocate compassion, suspicion, or marginalization with respect to the $g \bar{e} r$ ?

\section{The "Stranger": Who is the gēr?}

The conventional English translation "stranger" captures the Otherness implied in the uses of the term gêr in the Pentateuch. "Resident" or "sojourner" are more literal translations, and "resident alien" might be more precise, if a bit too legalistic, to convey the sense of marginality of this category. The geer is frequently clustered with the "orphan and widow," along with "the poor," in admonitions against abuse of the unfortunates in Israelite society, and in exhortations to extend care to those in need. The term thus indicates a member of a demographic group that is both included and excluded. In those texts, the stranger, orphan, and widow are set apart from the community that is being commanded to care for them, in whose midst they dwell. ${ }^{3}$

1 Citations follow the English translations of the Babylonian Talmud provided at https://www.sefaria.org. The sources for the translations are listed on the site.

2 Alternatively: "because his origin is evil." The Hebrew expression is unusual. A connection has been suggested between the word rendered here as "origin" or "inclination" and the word for fermented seed. See Shraga Abramson, "Midrash Milim - sor," Leshonenu 13 (1943-1944), 122-25. I thank Nadav Berger for this reference.

3 Inevitably, any use of categories and labels in order to alleviate the effects of "Othering" (marginalizing those perceived as strangers or different) will simultaneously function to inscribe and reinforce that Othering. In the twenty-first century, identity-sensitive politics grapple with the challenge: how does one identify and address the particular needs of an individual or group without reducing them to embodiments of that need or neediness? I do not detect sensitivity to the dangers of such reductionism in the texts examined here. 
Most of the legal portions of the Pentateuch are written in the form of reported dialogue, with Moses transmitting the words of God to the nation. When Moses addresses the people, the assumed "you" to whom he is speaking is a landowning male head of a family. Such full insiders are designated with such labels as Israelite, or "your brother," or "your friend/fellow" or a word often translated as "citizen" ('ezrah). Definitive outsiders are marked with the term "foreigner" (nokrî) or identified by affiliation with another nation or other nations, who are generally portrayed as hostile threats. The boundary-marking is less clear or consistent with respect to the geer, who lives within Israelite society but is marginalized due to ethnic identity. Bible scholars note distinctions, for example, between "Priestly" and "non-Priestly" legal texts with regard to the participation of "strangers" in rituals such as the celebration of sacred festivals, or obligations to observe dietary and purity restrictions. ${ }^{4}$ In rabbinic literature, a distinction is drawn between a "resident gēer" (gēr toshav) who accepts a minimal level of adherence to biblical law, e.g., the Noahide laws (Gen 9:1-17), and a "righteous gēr" (gēer tzedek) who is a full convert to Judaism.

Another variable is the origin of the geer. Most migrants entered the community through displacement from their original kinship base, as refugees or survivors of some natural, political, or personal distress, such as war or famine. In Deuteronomy, the demographic was most likely refugees from the Northern Kingdom of Israel to Judah, following the fall of the Northern Kingdom to Assyria in 722 BCE. In other texts, imagination and constructed memory played a role in the conception of the gēr. Some scholars have suggested that "protected citizens" (gērîm) are "primarily the pre-Israelite Canaanite population." Since most biblical scholars today posit that the Israelite community arose out of the indigenous population of the land of Israel, rather than having attained the land through conquest, it might be more appropriate to speak in historical terms of "non-Israelite" Canaanites. Within the world of the text, some "pre-Israelite" Canaanites would have remained in Israelite territory as liminal residents.

\section{Attitudes towards the gēr in the Pentateuch and Rabbinic Exegesis}

As noted, most of the legal texts concerning the gêr are commandments to care for the stranger and admonitions against mistreatment. The etymology of the word may point to some negative associations, however. The Hebrew root $g w r$ means simply "to dwell," but there might be some relationship between this root and homonyms meaning "to attack" or "to be afraid." Some linguists have suggested a connection to Akkadian geru, "to be hostile." Outright expressions of anxiety about the gêr are rare in the Hebrew Bible. One blatant occurrence is Deut 28: 43-44, in a passage warning about the curses that would befall the nation if they rejected their covenantal obligations: "Aliens (gêrîm) residing among you shall ascend above you higher and higher, while you shall descend lower and lower... they shall be the head and you shall be the tail." In contrast to this

4 See D. Kellerman, "geer" in TDOT 2:439-49. This perspective reflects the accepted critical view that the Pentateuch is a composite of multiple textual traditions, bearing traces of the disparate geographic and chronological contexts in which the various texts originated.

5 Ibid, 444.

6 Ibid., 439-40. A more whimsical but poignant etymology is suggested by Ibn Ezra: "gēr, from the berry (gargir) severed from the branch" (on Gen 15:13). On the tension between hospitality and hostility, see Richard Kearney, "Guest or Enemy? Welcoming the Stranger," ABC Religion and Ethics, 21 Jun 2012; http://www.abc.net.au/religion/articles/2012/06/21/3529859.htm. I am thankful to Philip Elman for calling this source to my attention. The tension is evoked in Derrida's neologism, "hostipitality," noted by Kearney. 
zero-sum oppositional perspective, the most common emotional framing for attitudes to the gēr is that of resonance and identification with the experience of being Other. In addition to the central Pentateuchal motif of the Israelites as strangers in the land of Egypt, a key element of the patriarchal narratives in the book of Genesis is that Abraham, Isaac, and Jacob and their households were themselves gērîm (described as "wandering Arameans" in Deut 26:5).

Identification with vulnerability can arouse wariness and defensiveness as well as empathy. Individuals and populations can be especially inclined to fear a vulnerable minority when their own status and welfare are not secure. Perhaps such motivation underlies R. Eliezer's anxious explanation for the multiplicity of biblical warnings against mistreating a $g \bar{e} r$, in which he used a strange idiom that I have suggested translating as "because his origin is evil." R. Eliezer's supposition is that converts are susceptible to backsliding, and so there is a practical danger that insensitive treatment would provoke regression to their former sinful ways. At the same time, the expression points to an essentialist view of the distinction between the convert and a natural-born member of the community.

What is most remarkable about the frequent citation of the Talmudic passage b.Bava Metzia 59b in modern homiletics and apologetics is that there is an alternative version of Rabbi Eliezer's statement in an earlier rabbinic compilation, the midrash Mekhilta of R. Ishmael (ch. 22). ${ }^{7}$ In the midrash, the attributed statement is simpler and perhaps less quotable as a soundbite and, more importantly, it is clearly a minority opinion in a passage that is highly positive towards gērim. A fuller citation will clarify the dominant thrust of the Mekhilta:

\footnotetext{
"You shall not wrong or oppress a gèr, for you were gērîm in the land of Egypt." You shall not wrong him with words and you shall not oppress him in money matters. Do not say to him, "Yesterday you worshipped Bel, Kores, Nebo, and (the flesh of) swine is still between your teeth, and you would dare to contend with me!"
}

And whence is it derived that if you taunt him then he can taunt you in return? From, "And a stranger you shall not afflict... for you were strangers in the land of Egypt"-from here, R. Nathan derived, "Do not attribute a blemish of your own to your neighbour."

Beloved are the strangers, for in many places you are exhorted concerning them: "And a stranger you shall not afflict" (Exod 22:20); "And you shall love the stranger" (Deut 10:19); "And you have known the soul of the stranger" (Exod 23:9).

R. Eliezer says: Because a stranger's past is to his disadvantage, Scripture exhorts concerning him in many places. ${ }^{9}$

R. Shimon b. Yochai says: It is written, "And His (God's) lovers are like the rising of the sun in its might" (Judges 5:31), and it is written "And He loves the stranger etc." (Deut 10:18). Now who is greater? One who loves the King or one whom the King loves? Certainly, one whom the King loves....

In the midrash, unlike in the Talmud, R. Eliezer's view is a parenthetical interruption to the thrust of the passage, which is highly complimentary to the $g \bar{e} r$. His is a lone counter voice to a

7 See also Tractate Gerim, ch. 4.

8 In contemporary English idiom: "Pot, do not call the kettle black," as rendered by Aryeh Newman, in his translation of Nehama Leibowitz, New Studies in Shemot: The Book of Exodus, trans. Aryeh Newman (Jeruslaem: Haomanim, 1995), 383.

9 The expression is the same as that in the Talmud: because his origin, or original nature, or inclination, or "fermentation," is bad. See f.n. 2. 
primary, and presumably majority accepted opinion. The remainder of the passage is devoted to prooftexts supporting linguistic and historical equation of the gêrîm and the nation of Israel as a whole:

Beloved are the gêrim, for by every epithet that Israel is called, the strangers are called.

Israel is called "servants" as it is written, "For unto Me the children of Israel are servants" (Lev 25:55) and the gêrîm are called "servants" as it is written "to love the name of the LoRD and to be servants unto Him" (Isa 56:6).

Israelites are called "ministers" as it is written, "And you, 'priests of the LORD' shall you be called; 'ministers of our God' will it be said of you" (Isa 61:6) and the gērîm are called "ministers" as it is written "And the gêrîm who join the LoRD to minister unto Him" (Isa 56:6) ... Abraham called himself a gēr...

David called himself a $g \bar{e} r$....

The different frames of R. Eliezer's statement in the Talmud and the Mekhilta point to the multivocality of Jewish tradition. This preservation of multiple views highlights the personal responsibility of subsequent readers who look to canonical religious texts for meaningful and authentic guidance in our practical lives.

\section{Additional Rationales for Sensitivity to the Stranger: Imitatio Dei, Accountability, Empathy}

The Mekhilta's equation of the status of gêrîm with that of Israel includes an appeal to the biblical assertion of God's love of the geer, in Deut 10:18: "He defends the cause of the fatherless and the widow, and loves the stranger, giving him food and clothing." That verse is followed by the command, "And you are to love those who are strangers, for you yourselves were strangers in Egypt."

Rabbi Eliezer's statement about "warnings" against mistreating the gēr offers a logical basis for the numerous negative prohibitions, but it is less effective as an explanation for the positive commandments to "love the stranger." I suggest that the sequence of the verses in Deut 10 points to Imitatio Dei as a basis for this love; Israel is to follow divine example by adopting a protective stance towards the stranger. The same juxtaposition is found in Lev 19:34: "You shall love the alien ( $g \bar{e} r)$ as yourself, for you were aliens in the land of Egypt: I am the LoRD your God."

The medieval Spanish commentator Nachmanides (1194-1270) drew a more prosaic connection between God's special protection of the gēr and Israel's obligation in his interpretation of Exod 22:20:

And that which is correct in my eyes is that when it states "do not wrong the gêr and do not oppress him"... you might think that he has no one to save him from your hand, since you know that you were strangers in the land of Egypt and you saw the harrying that Egypt harried you and that I (God) took vengeance for you .... And so too do not afflict the widow and the orphan since I hear their cries. As all of these do not rely on themselves and so they rely upon Me.

Nachmanides suggested that the effectiveness of the Exodus narrative as a deterrent against mistreatment of gêrîm lies in the negative example of the punishment of the Egyptians. Israelites might have been inclined to think, wrongly, that they would not be held accountable for taking advantage of somebody who lacks conventional societal protectors; recalling the national experience in Egypt will remind them that God protects the vulnerable, and avenges abusers, and this memory will spur them to refrain from wrongdoing. 
Nachmanides proceeds to cite Exod 23:9:

And in another verse he added this reason: for you know what it feels like to be a stranger, because you were strangers in the land of Egypt. That is to say, you know that every stranger feels depressed, and is always sighing and crying, and his eyes are always directed towards G-d, therefore He will have mercy upon him even as He showed mercy to you, as it is written, and the children of Israel sighed by reason of the bondage, and they cried, and their cry came up to God by reason of the bondage, meaning that He had mercy on them, not because of their merits but only on account of the bondage.

For Nachmanides, knowing the soul (nepeš) of the gèr means recognizing the painful reality of the condition of Otherness, and acknowledging that this reality will lead gêrim to a situation in which they will merit divine vengeance against any who oppress them. This is different from the stance of R. Eliezer, for whom knowing the "soul" of the gêr meant attributing an essential wickedness to the Other. ${ }^{10}$ Nevertheless, the position is rooted in concern for one's own self-protection: Do not oppress the gêr, because you know they will cry out and God will avenge them.

Jonathan Sacks, former Chief Rabbi of the United Hebrew Congregations of the Commonwealth, writes about Nahmanides' comment:

According to Nachmanides the command has two dimensions. The first is the relative powerlessness of the stranger ... This is the political dimension of the command. The second reason, as we have already noted, is the psychological vulnerability of the stranger ... That is the emotive dimension of the command. ${ }^{11}$

I would suggest that this interpretation misses the rhetorical thrust and context of Nachmanides' comments. Nachmanides is explaining how the Torah's statement about divine protection functions as a motivational deterrent to oppressing geerîm: the oppressed will cry out, and God will hear them and avenge them. Nachmanides explains that Israelites should know this will happen because of their own experience in which God saved them from affliction in Egypt. And he adds that they should know from personal experience that afflicted people will indeed cry out and set this process in motion. Nachmanides is identifying the "emotive dimension" of the experience of being a gerr, but he is not clarifying an emotional motivation for the biblical commands about treatment of the $g \bar{e} r$. The concern in Nachmanides' comment is pragmatic self-preservation by the Israelites, rather than an emotional or ethical appeal. This is a strategic application of the Israelites' empirical knowledge about the suffering of the oppressed, and about divine compassion, rather than a reflection on human compassion.

The identification of such an ethical component is more readily visible in the exegesis of Nachmanides' predecessors Rashi (1040-1105, the medieval Jewish commentator par excellence $)^{12}$ and Abraham Ibn Ezra (1089-1167), "when a gēr accepts upon himself not to worship idolatry, do not oppress him in your land, because you have greater power than he, and remember that you were strangers like him" (on Exod 22:20). It seems likely to me that Ibn Ezra's interpretation captures

10 R. Eliezer does not cite the verse, but his statement appears to be an exegetical comment on "knowing the soul." I would suggest that the comment of Rashi on Exod 23:9 reflects a rejection of such a reading: " "for you know the soul of the gēr': how hard it is for him when people oppress him," i.e., emphasizing that what is known is the experience of the gêr, not his essence or origin. Nehama Leibowitz notes that Rashi's use of the term "oppress" serves as an intertextual link to Exod 3:9, in which God assures Moses "Now therefore, behold, the cry of the children of Israel is come unto me: and I have also seen the oppression wherewith the Egyptians oppress them" (KJV).

11 http://rabbisacks.org/covenant-conversation-5768-mishpatim-loving-the-stranger/

12 See footnote 10 . 
the meaning of the verse in its original context: the Pentateuchal instructions about proper treatment of the gêr are bolstered by motivational exhortations towards empathy, through memory and identification.

The Sefer Hachinuch $\left(\S 432 ; 13^{\text {th }} \text { cent. }\right)^{13}$ offers both motivations of the self-interested investment in divine reward and the ethical-psychological "emotive" commitment to acting mercifully (as emphasized in the italicized text):

And this commandment is practiced in every place and at all times by males and females. And one who transgresses it ... due to their being converts and not having a helper in the nation, has nullified this positive commandment; and his punishment is very great, as behold, the Torah has warned about them in several places. And we should learn from this precious commandment to have mercy on a man who is in a city that is not the land of his birth and the place of the family of his fathers. And we should not pass him by on the road when we find him alone and that his helpers are far from him, since we find that the Torah warns us to have mercy on anyone who needs help. And with these traits, we will merit to receive mercy from God, may He be blessed, and the blessings of Heaven will rest upon our heads. And Scripture hints to the reason of the command when it states, "since you were strangers in the Land of Egypt": It mentions to us that we were previously burnt by this great pain that there is to every man who sees himself among foreign people and in a foreign land. And upon our remembering the great worry of the heart that there is in the matter, and that it already passed over us and that God, in His kindnesses, took us out of there, our mercies for any person like this will overwhelm $[u s]$.

Rabbi Samuel David Luzzatto (1800-1865) further elaborated upon the two-faceted biblical motivation for the command: the appeal to self-interest in the form of divine reward and punishment and a higher form of encouragement towards honing the human propensity for mercy. In his exegesis of Exod 22:20, Luzzatto cited the commentary of Rabbi Moses Mendelsohn (1729-1786), who wrote: "And someone who was in trouble and distress, and God saved him, it is fitting that he will have mercy on all who enter into that distress, and so it is in the nature of the human spirit that one's mercy is bestirred when he sees a fellow human undergoing suffering that he himself has felt in the past."

\section{“Remember!”: Memory, Identity, and Narrative; Trauma; Continuity and Change}

The logical assumption underlying the comments of Rashi, Ibn Ezra, the Sefer Hachinuch, Mendelsohhn, and Luzzatto is that recalling one's own former victimization functions as an impetus towards empathy and meritorious conduct. Yet Nehama Leibowitz challenges the supposition that "past memories and experiences of strangeness and slavery" will naturally breed empathy: "Do we not often find the opposite to be the case?... How often do we find that the slave or exile who gains power and freedom, or anyone who harbours the memory of suffering to himself or his forbears, finds compensation for his former sufferings by giving free rein to his tyrannical instincts, when he has the opportunity to lord it over others?"14

Shmuel Klitsner addresses how trauma can sometimes have this negative effect by entrenching a victim in a narrative of remembered suffering and vulnerability. He writes:

13 A compendium of descriptions of biblical commandments, composed in Spain in the thirteenth century. The unknown author followed the list of 613 commandments compiled by Maimonides, in keeping with the number cited in early rabbinic tradition (inter alia, b.Makkot 23b; Sifre, Deuteronomy 76).

14 Leibowitz, New Studies in Shemot, 384. 
The professional literature on this takes caution to stress that only a small percentage of the abused become abusers, while, at the same time, a large percentage of abusers were formerly abused. . . there seems to be an inability on the part of the victim to see himself as now playing the role of the perpetrator. It is as if the sense of victimization grants the victim more than a history; it confers an identity. This identity, in turn, becomes an immunity card, as the identities of victim and victimizer are seen as mutually exclusive by the person who has become both. ${ }^{15}$

One component of the process of transforming negative experience into positive sensitivity and support of others is cultivating a sense of appreciation of one's changed status. The constructive power of the memory of powerlessness is contingent upon recognition of the contrast between that traumatic memory and a current state of empowerment. As specified by Ibn Ezra: "because you have greater power than he," and in the Sefer Hachinuch: "that it already passed over us and that God, in His kindnesses, took us out of there." An appreciation of new power dynamics can help survivors of trauma see themselves as both former victims and current wielders of authority and responsibility.

The Hebrew Bible is very aware of the significance of memory for constructing, fortifying, and reconstructing identity, and for adapting personal and national narratives to historical developments. The particular injunction to "remember that you were a slave" is used as a motive clause for a number of commandments: observing Shabbat (Deut 5:15); providing an indentured slave with money upon his release (15:15); observing festivals (16:12; and also for including the needy in the rejoicing of the festival); and a prohibition against financial or judicial mistreatment of $(24: 18,22)$. Deut $16: 3$ and 24:18 specify remembering the exodus and redemption, in addition to the enslavement. ${ }^{16}$

Leibowitz suggests that the double incentive towards sensitivity to gêrim in Deuteronomy addresses different types of people: "Some will be sufficiently moved by the memory of their experience of oppression at the hands of others to put themselves in the stranger's shoes... On the other hand, those not prompted by their own experience of similar suffering to act kindly to the stranger in their midst, will, at least, be influenced by the argument of the victim of their oppression, 'If you wrong him, he will wrong you back." 17 I suggest that Deuteronomy does more than offer two separate incentives. It directs the Israelites towards a constructive use of memory and narrative. The text encourages readers to look back at their own suffering as a means to generate empathy, not because this is universal and natural, but precisely because it is a difficult and uncertain process, and requires cultivation.

\section{The Narrative of the Narrative}

Just as memory of victimhood has the power to either (or both?) reinforce helplessness and generate empowerment, so too can self-conceptions of morality serve to either reduce or increase moral conduct. A Google search for " 36 times stranger Jewish" (from the 36 warnings about treatment of strangers in b. Bava Metzia 59b) yields hundreds of results related to the idea of loving the stranger in Jewish sources. ${ }^{18}$ Many of these are affirmations of Jewish traditions

15 Shmuel Klitsner, "Victims, Victimizing and the Therapeutic Parable: A New Interpretation of II Samuel Chapter 12," Tradition 46 (2013): 25-42. I am thankful to Ricki Heicklen for this reference.

16 Aryeh Bernstein, personal communication.

17 Leibowitz, New Studies in Shemot, 385.

18 A raw Google search returned millions of hits, but due to the complex nature of Google algorithms concerning hits and hit counting, I determined to focus only on meaningful results and follow up with a reference. 
of sensitivity to others, such as: "Our most sacred text delivers a universal message about Jewish commitment to human rights and refugee protection." 19 A challenge that arises is that such self-congratulatory remarks can lead to a sense of exceptionalism that can ultimately encourage isolationism over openness. "Caring for the Other" becomes a descriptive affirmation of what Jewish people are, rather than a prescriptive exhortation about what Jewish tradition should motivate people to $d o$. An impulse to parade textual traditions about sensitivity to strangers as evidence of Jewish universalism can take on a very particularist counter-function of proclaiming Jewish morality, or even superiority. Even awareness of this hazard might not be sufficient to mitigate the phenomenon. Sacks writes:

Concern for social justice was not unique to Israel. What we sense, however, throughout the early biblical narrative, is the lack of basic rights to which outsiders could appeal. Not by accident is the fate of Sodom and the cities of the plain sealed when they attempt to assault Lot's two visitors...So it was in the ancient world. Hatred of the foreigner is the oldest of passions, going back to tribalism and the prehistory of civilisation. The Greeks called strangers "barbarians" because of their (as it seemed to them) outlandish speech that sounded like the bleating of sheep..."20

Sacks provides a long list of biblical texts describing xenophobia by non-Israelites, and proceeds to offer historical examples of European violence against Others, leading to a claim that Western thought is inadequate for ensuring ethical treatment of the stranger: "Enlightenment thought is marked by two great attempts to ground ethics in something other than tradition. ... Neither Kantian reason nor Humean emotion were strong enough to inoculate Europe against genocide... It is as if the Torah were saying with the utmost clarity: reason is insufficient. Sympathy is inadequate. Only the force of history and memory is strong enough to form a counterweight to hate."

Sacks ends his essay forcefully:

"Why should you not hate the stranger? - asks the Torah. Because you once stood where he stands now. You know the heart of the stranger because you were once a stranger in the land of Egypt. If you are human, so is he. If he is less than human, so are you. You must fight the hatred in your heart as I once fought the greatest ruler and the strongest empire in the ancient world on your behalf. I made you into the world's archetypal strangers so that you would fight for the rights of strangers - for your own and those of others, wherever they are, whoever they are, whatever the colour of their skin or the nature of their culture, because though they are not in your image - says G-d - they are nonetheless in Mine. There is only one reply strong enough to answer the question: Why should I not hate the stranger? Because the stranger is me."

I find this rhetoric persuasive and moving. And yet. It is all too easy for the empathetic recognition that "the stranger is me" to give ground to a defensive conviction that "I am the stranger" even when one is in actuality in the position of host. Sacks says, "To be a Jew is to be a stranger." When this stimulates empathy, this is a useful reading of Bible and Jewish tradition. When it becomes a flat badge of identity, it can become an obstacle to recognizing strength and responsibility. Deuteronomy says dramatically, "you were slaves in Egypt" and commands the Israelites to preserve this vividness of memory, to tell their sons and future generations of their personal experience. Even in the narrative world of the biblical book, however, the "you" being addressed are the

19 http://jewishjournal.com/opinion/215385/embracing-jewish-communitys-refugee-roots/.

20 http://rabbisacks.org/covenant-conversation-5768-mishpatim-loving-the-stranger/ 


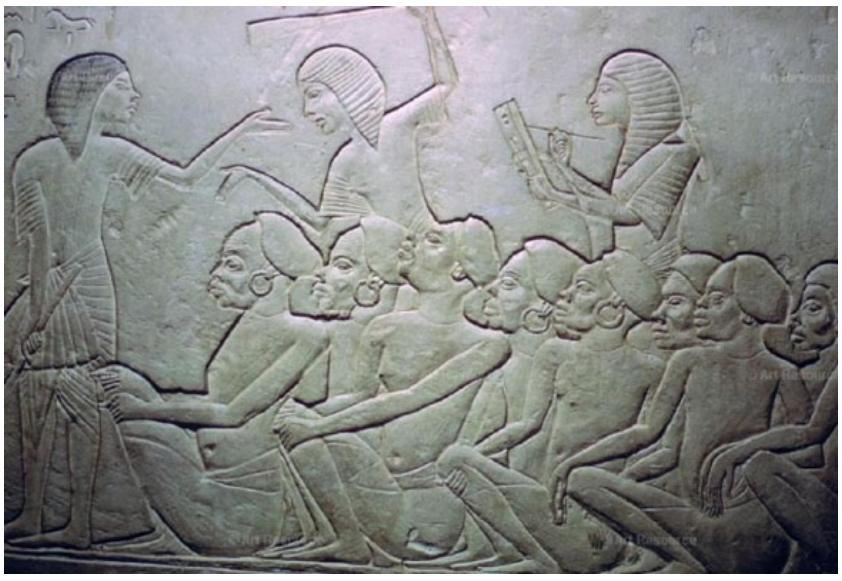

Figure I. Detail of an Egyptian stele showing an overseer, slaves, and scribe. Musee Guico, Bologna, Italy. HIP/Art Resource, NY.

members of a new generation, most of whom had not experienced the enslavement or exodus first hand. ${ }^{21}$

Deuteronomy exhorts the Israelites to remember, to retell, to re-enact and to anticipate future retellings and re-enactments of divine redemption and revelation. This is an effective means of forging and fortifying identity and motivating readers towards ethical behaviour, social justice, morality, and sensitivity. At the same time, it is an approach that contains the danger of complacency, which can lead to apathy or blindness to changing realities. In order to make use of the memory of oppression, it is essential for survivors of trauma to learn to recognize, cultivate, and use their emerging strengths.

\section{“Do not Abhor an Egyptian": Hospitality and Hostility22}

This necessity to use our imaginative faculties to stand in others' shoes may offer some insight for deciphering the most puzzling text about treatment of gêrîm, Deut 23:7(8):

You shall not abhor any of the Edomites, for they are your kin. You shall not abhor any of the Egyptians, because you were an alien residing in their land. The children of the third generation that are born to them may be admitted to the assembly of the Lord.

There is a jarring disjunction in this verse between the motive given for openness towards Edomites - namely kinship, as compared to the motive for tolerance towards Egyptians - the history of enslavement in Egypt. Some exegetes account for this surprising latter motive clause by explaining that the reference to being "strangers" in Egypt is not a reference to the period of enslavement (as recounted in Exod 1-14), but rather to the prior era of Israel's sojourn in Egypt in the time of famine (Gen 47:11, 27). Maimonides writes that this verse teaches that one must recall prior benefits extended by somebody who subsequently harms as, just as the previous hospitality of the Egyptians must be born in mind, despite their later oppression of Israel (Guide of the Perplexed, 3.42). Similarly, Rashi states: "all in all (utterly), although they cast your male children into the river. And what is the reason that you should not abhor him utterly? Because they were your hosts in time of need (note: during Joseph's reign when the neighbouring countries suffered from famine); therefore although they sinned against you do not utterly abhor him." This interpretation seems to me to run counter to the centrality of redemption in the national story developed in the Pentateuch. Egypt represents oppression, from which Israel was delivered, not sustenance and refuge.

21 See Rachel Farbiarz, "Treatment of the Stranger," http://www.myjewishlearning.com/article/ treatment-of-the-stranger/.

22 See n. 6 above. 
I have considered an alternative reading of the verse that would preserve the sense of Israelite experience of Otherness in Egypt as oppression, by understanding the two "because" clauses in the verse as having different functions, with the latter case presenting a rejected rationale: "Do not hate the Egyptians on account of the fact that you were an alien residing in their land." In this reading, the text is taken to acknowledge and negate a potential natural inclination to vengefulness towards one's oppressors. It commands, instead, a limitation on the bearing of such grudges. This is a reading that resonates with me personally, as a Jewish Bible scholar living and working in Germany. ${ }^{23}$

A more creative interpretation has been put forth by Rabbi Aryeh Klapper, who discerns a logical progression across the Pentateuch's commands about gêrim. ${ }^{24} \mathrm{He}$ discerns a move from "abstract intellectual argument" in Exod 22:20 — do not accuse others of a flaw that you have (Exod 22:20) - through an appeal to emotionally-engaged empathy, "knowing the soul" (Exod 23:9), and further to identification: equality of treatment, and, beyond the avoidance of harm to positive love (Lev 19:33-34). Klapper sees Deuteronomy as "harvesting and summing up" the earlier progression (Deut 10:19). He then suggests that in Deut 23:8, the prior assumption that Israelite experience in Egypt was "one of oppression... is completely upended, even falsified.... Here the experience of Egypt seems to be recalled as positive; it generates an obligation to treat Egyptians as relatives rather than as strangers."

Klapper suggests that this change in view aims "to ensure that our formative memory of our time in Egypt does not calcify into chauvinism, but rather serves as a constant reminder to appreciate both commonality and uniqueness."

I find Klapper's reading appealing, and I think his insights can be illuminating for understanding Deut 23:8, even for those who do not see the Pentateuch as a unified sequentially coherent composition. I suggest adapting his lens with an aim to warning the Israelites against turning into oppressors. The text would then urge: Do not hate the Egyptians, because you are like them. Edomites seem like Others, but they are your brothers. Egyptians seem like Others, foreign, utterly unrelatable - but you know that they are like you, because you lived among them. You experienced the oppressors as human beings, not as tropes or monsters but as real people with cares and concerns and feelings and thoughts, who nevertheless treated you so cruelly. The aim of such a realization would be to sensitize the addressees (ancient Israelites, and future generations of readers) to the dangers of becoming oppressors. We must not seek a corrective for former traumas through prolonged rejection of descendants of Egyptians. Rather, we must pursue a redemptive path, through time and healing, towards welcoming those descendants into our own redeemed community.

We must love the strangers because we remember the experience of being strangers. That memory is an aid towards bringing us to want to treat others as we would have wanted to be treated. So too, we must not hate the descendants of our oppressors. The memory of our oppression must be an

23 Germany today is pulsing with reminders of the unspeakable suffering that my people experienced as strangers in their European homelands. Some of my family and contemporaries have opposed interaction with Germans. I understand the discomfort that many Jewish people have today about visiting Germany, buying German products, or interacting with Germans of the third and now fourth generation. And I feel that it is important that we overcome this discomfort, particularly in light of Germany's staunch commitment to confronting its past through Holocaust education and commemoration.

24 Aryeh Klapper, "Pesach, Ki Gerim," Center for Modern Torah Leadership, 2015. http://www.torahleadership.org/categories/pesach_2015.pdf. I am thankful to Aryeh Bernstein for this reference. A hint of such an interpretation may be found in Leibowitz, New Studies in Shemot, 385, "They will graduate from the negative injunction ..." 
aid towards recalling the humanity of those oppressors, so that now, when the tables have turned, and we are in a position to reject their descendants, we will use our powers of choice to make the decisions that their ancestors should have made.

\section{Conclusion: Fear and Love}

Countries that serve as destinations for refugees and asylum-seekers face many serious ethical and practical dilemmas. Biblical texts cannot offer policymakers pragmatic assistance in assessing budgets, absorption capacity, admission criteria, optimal geographic integration and myriads of other challenging decisions. They can, however, help us all construct and conduct a discourse that will enable us to think more clearly, sensitively, and effectively about optimal attitudes and approaches to these challenges.

In many countries, political groups agitate against immigrants, particularly through the promotion of fear. Fear can be an effective instrument for garnering political power, but it is counterproductive for coming up with useful policies. It is far more effective to act from a position of strength and an awareness of strength.

It is noteworthy that in the sources explored in this essay, the few that reflected anxiety about the threats posed by Others saw such fears as a motivation for kindness. Even R. Eliezer's xenophobic statement was offered as a rationale for the necessity for kind treatment of strangers. Alienating behavior would be the most dangerous stance to adopt towards an alien who is perceived as dangerous. This message is worth promulgating: for those who fear refugees, the most empowering solution is kindness. Those who see vulnerable migrants as posing a threat to their own majority culture, economy, or security, can best minimize that threat by adopting an attitude of support and assistance with an aim towards healthy integration.

America has traditionally prided itself on being the land of opportunity, celebrating narratives of "self-made men" overcoming hardship. Individually and nationally, this potentially inspiring exceptionalism can lead to self-images in which identity becomes an immunity card. Those who believe they have "picked themselves up by their own bootstraps" often cannot see when they are stepping on the feet of bootless Others. ${ }^{25}$ We have a tendency to be self-congratulatory about our own successes and to invite others to marvel at our against-the-odds achievements, while at the same time judging others negatively for not having matched those remarkably exceptional achievements.

The book of Deuteronomy helps cultivate a healthy and constructively appreciative sense of past hardship, current prosperity, progress, and relative privilege. In contemporary culture, the term "privilege" has become an unfortunate source of contention. Deuteronomy might point a way for recognition of one's relative privilege vis-à-vis an Other to be embraced as a basis for gratitude and responsibility. We have gained "privilege" after having been immigrants, strangers in a strange land. What if "checking one's privilege" could become an empowering and challenging exercise of

25 The allusion is to Martin Luther King's address "Remaining Awake through a Great Revolution" at the National Cathedral, Washington, DC, on March 31,1968, four days before he was murdered: "It's all right to tell a man to lift himself by his own bootstraps, but it is a cruel jest to say to a bootless man that he ought to lift himself by his own bootstraps." The full text of the speech can be found at: kingencyclopedia.stanford.edu/encyclopedia/documentsentry/doc_remaining_awake_through_a_great_revolution/. 
counting one's blessings and considering how these could be used for the benefit of others, including strangers to our land?

Love the stranger, and do not shut out the descendants of Egyptians, for you were strangers in the land of Egypt, but God redeemed you. As the Israelite is enjoined to say, when bringing the offering of first-fruits:

\begin{abstract}
A wandering Aramean was my ancestor; he went down into Egypt and lived there as an alien, few in number, and there he became a great nation, mighty and populous. When the Egyptians treated us harshly and afflicted us, by imposing hard labor on us, we cried to the LORD, the God of our ancestors; the LORD heard our voice and saw our affliction, our toil, and our oppression. The LoRD brought us out of Egypt with a mighty hand and an outstretched arm, with a terrifying display of power, and with signs and wonders; and he brought us into this place and gave us this land, a land flowing with milk and honey. So now I bring the first of the fruit of the ground that you, O LORD, have given me." You shall set it down before the LoRD your God and bow down before the LORD your God. Then you, together with the Levites and the aliens (gêrim) who reside among you, shall celebrate with all the bounty that the LORD your God has given to you and to your house (Deut 26:5-11).
\end{abstract}

